\title{
COPPER STRESS ON CELLULAR CONTENTS AND FATTY ACID PROFILES IN CHLORELLA SPECIES
}

\author{
Sibi, G., T.S. Anuraag and Geeta Bafila \\ Department of Biotechnology, Indian Academy Degree College, \\ Centre for Research and Post Graduate Studies, Bangalore, India
}

Received 2014-07-09; Revised 2014-07-22; Accepted 2014-08-18

\begin{abstract}
Higher photosynthetic efficiency and biomass production with rapid growth makes microalgae as potential candidates over other energy crops in many applications. Heavy metals influence the production of secondary metabolites and lipd content of microalgae in particular. A study was conducted using six Chlorella species under heavy metal exposure to evaluate the copper stress on biomass, cellular and lipid contents. Preliminary growth studies indicated the growth tolerance levels of Chlorella in the presence of copper at $4.0 \mathrm{mg} \mathrm{L}^{-1}$ concentration. The total chlorophyll, protein and lipid content of the isolates were $1.7-3.45 \%, 0.43-0.70 \mathrm{mg} \mathrm{g}^{-1}$ and $0.02-0.11 \mathrm{mg} \mathrm{g}^{-1}$ respectively. Gas Chromatography-Mass Spectroscopy analysis revealed that the percent composition of fatty acids varied among the species studied and the major group of fatty acids were C16:0, C18:1 and C18:2. Highest percent of fatty acids were found in C. vulgaris, C. protothecoides and C. pyrenoidosa. Copper have an impact on Chlorella species where biomass content was directly proportional to the lipid productivity. The results reflects the fact that copper stress on Chlorella species as the evidence of lipid production in both qualitative and quantitative manner. In conclusion, Chlorella species can be used for the sustainable producion of renewable energy through copper stress and removal of copper from aqueous solutions.
\end{abstract}

Keywords: Chlorella, Lipid Productivity, Heavy Metal, Abiotic Stress, Copper

\section{INTRODUCTION}

Microalgae are used for many applications which include biofuel production, heavy metal removal, production of pharmaceuticals and nutraceuticals. Further, microalgae have advantages over other energy crops due to their higher photosynthetic efficiency, higher biomass production and faster growth (Huang et al., 2010; Chisti, 2007). The survival or proliferation of microalgae over a wide range of environmental conditions results in the production of many secondary metabolites (Anderson,
1996). Lipids are secondary metabolites produced by microalgae helps in maintaining specific membrane functions and cell signalling pathways while responding to the environment changes. The fatty acid content is influenced by the environmental and cultural conditions of microalgae (Petkov and Garcia, 2007).

Algal lipids have been recognized as suitable feedstock for biodiesel production (Griffiths and Harrison, 2009). Algae synthesize fatty acids principally for esterification into glycerol based polar lipids under favourable conditions. However, many algae alter their lipid biosynthetic pathways towards algae alter their lipid bio

Centre for Research and Post Graduate Studies, Bangalore, India 
the formation of neutral lipids in the form of triacylglycerol (Breuer et al., 2012; Li et al., 2011a) and can be readily converted to biodiesel (Hu et al., 2008). The lipid content can be altered by various factors (Hsieh and $\mathrm{Wu}, 2009$; Rodolfi et al., 2009; Takagi and Yoshida, 2006; Liu et al., 2008) including heavy metals (Dragone et al., 2011; Rocchetta et al., 2006; Sunda et al., 2005; Vavilin et al., 1998). Copper has been used as pesticide to control algal blooms (Rai et al., 1981; Horne and Goldman, 1974) which disrupts photosynthesis, respiration, ATP production, pigment synthesis and inhibits cell division (Cid et al., 1996; Stauber and Florence, 1987). Copper is associated with large number of enzymes which catalyse oxidative reactions involving metabolic pathways (Marschner, 1995). However, little information is available on the effect of copper in modulating the fatty acid composition of Chlorella species. In this study, variations in lipid composition are compared with the concentrations of biomass, chlorophyll, protein and lipid content in order to elucidate the influence of copper stress on various Chlorella species.

\section{MATERIALS AND METHODS}

\subsection{Sample Collection and Identification}

Algal samples were collected from copper contaminated water habitats from Bangalore $\left(13^{\circ} 04^{\prime} \mathrm{N}\right.$, $\left.77^{\circ} 58^{\prime} \mathrm{E}\right)$ and washed several times with tap water and then with deionized water before analysed by using microscope. The family and genus were identified with reference to the biology of algae (Round, 1973).

\subsection{Cultivation}

Six Chlorella species were identified and were cultivated in Bold's basal medium (Andersen, 2005; Stanier et al., 1971) and http://web.biosci.utexas.edu/utex/default.aspx).

\subsection{Copper Concentration}

Stock copper solutions $\left(\mathrm{CuCl}_{2} \cdot 2 \mathrm{H}_{2} \mathrm{O}\right)$ were prepared at a concentration of $100 \mathrm{mg} \mathrm{L}^{-1}$ in deionized water. Solutions of varying concentrations were prepared by diluting with Bold's basal medium.

\subsection{Heavy Metal Tolerance Studies}

To determine algal tolerance to copper, exponential growth phase $\left(10^{4}\right.$ cells $\left.\mathrm{m} \mathrm{L}^{-1}\right)$ algal cultures were used
(OECD, 2002). Bioassays were carried out in $250 \mathrm{~mL}$ conical flasks containing $100 \mathrm{~mL}$ of Bold's basal media supplemented with $\mathrm{Cu}$ at initial concentrations ranging from $0.5,1.0,2.0,4.0$ and $8.0 \mathrm{mg} \mathrm{L}^{-1}$. The flasks were kept under illumination at 2500 lux for 12 hr light-dark cycle at $24 \pm 2^{\circ} \mathrm{C}$ and agitation in an orbital shaker for 15 days. Metal-free and algae-free blanks were used as control groups. Separation of biomass from metal bearing solution after appropriate incubation time was achieved through centrifugation at $10,000 \mathrm{rpm}$ for $10 \mathrm{~min}$.

\subsection{Cell Count and Biomass Determination}

The cells were fixed with Lugol's iodine solution to measure the cell density using haemocytometer. The mean number of cells produced at each concentration after the incubation period was expressed as percentage growth reduction with respect to control. The algal biomass was determined by the spectrophotometric transmission of algal suspension (Schimadzu UV-2600) at $550 \mathrm{~nm}$. The highest concentration of copper which produced maximum biomass content was used for further studies.

\subsection{Chlorophyll Estimation}

The chlorophyll content of the cells was estimated spectrophotometrically (Sartory and Grobbelaar, 1984). The cells were harvested by centrifugation at $3000 \mathrm{~g}$ and thoroughly ground in $96 \%$ ethanol. After incubation with ethanol for $2 \mathrm{~h}$ at $4^{\circ} \mathrm{C}$, cell debris was cleared by centrifugation. The resulting supernatant was subjected to OD measurement at the wavelength of $645 \mathrm{~nm}$ and $663 \mathrm{~nm}$, with $96 \%$ ethanol as blank. Total chlorophyll content (i.e., chl a and b) was estimated using a formula $\mathrm{C}\left(\mathrm{mg} \mathrm{L}^{-1}\right)=20.2 \mathrm{OD}_{645}+8.05 \mathrm{OD}_{663}$ and was converted to $\%$ of cell dry weight.

\subsection{Total Soluble Protein Estimation}

Total soluble protein content was measured by the (Bradford, 1976) method using bovine serum albumin as standard. The total soluble protein was expressed as $\mathrm{mg} / \mathrm{g}$ fresh weight.

\subsection{Lipid Extraction}

Algal cultures were centrifuged and the pellet was added with $10 \mathrm{~mL}$ of ice cold $0.2 \mathrm{~N} \mathrm{HClO}_{4}$. After $15 \mathrm{~min}$ at $4^{\circ} \mathrm{C}$, the sample was centrifuged and $10 \mathrm{~mL}$ of chloroform-methanol $(2: 1 \mathrm{v} / \mathrm{v})$ solution was added and allowed to stand for $5 \mathrm{~min}$ at $4^{\circ} \mathrm{C}$. The sample was 
centrifuged and to the supernatant, 0.2 volumes of distilled water were added. The solutions were shaken for $5 \mathrm{~min}$ and centrifuged for $15 \mathrm{~min}$ at $2000 \mathrm{rpm}$ to separate the phases. The lower organic phase was collected and the chloroform-methanol solution was evaporated under a steam of nitrogen. Aliquots of lipid extracts were mixed with $2 \mathrm{~mL}$ of dichromate solution and the tubes were placed in boiling water bath for $45 \mathrm{~min}$. The tubes were shaken for 2 or 3 times during the heating and were cooled, removed $1 \mathrm{ml}$ from each, diluted to $100 \mathrm{~mL}$ with water and the absorbance was read at $350 \mathrm{~nm}$ against water as blank. Palmitic acid was used a standard and the lipid content was determined from the standard curve (Folch et al., 1957).

\subsection{Fatty Acid Methyl Ester (FAME) Analysis}

Algae cultures (4 mL each) were centrifuged at $16,000 \mathrm{rpm}$ for $3 \mathrm{~min}$ and the pellet was hydrolyzed and methyl-esterified by shaking $(1,200 \mathrm{rpm})$ with $300 \mu \mathrm{L}$ of a $2 \% \mathrm{H}_{2} \mathrm{SO}_{4} /$ methanol solution for $2 \mathrm{~h}$ at $80^{\circ} \mathrm{C}$. This was followed by the addition of $50 \mu \mathrm{g}$ of hexadecanoic acid as internal standard to the pellet prior to the reaction. A total of $300 \mu \mathrm{L}$ of $0.9 \%(\mathrm{w} / \mathrm{v})$ $\mathrm{NaCl}$ and $300 \mu \mathrm{L}$ of hexane was then added and vortexed. Phase separation was performed by centrifugation at $16,000 \mathrm{rpm}$ for $3 \mathrm{~min}$. A total of 1 $\mu \mathrm{L}$ of the hexane layer was used for GC-MS analysis.

\subsection{GC-MS Conditions}

GC-MS analysis of lipid extract was performed using a Thermo Scientific TRACE GC Ultra comprising an Thermo DSQII auto-sampler equipped with Zebron ZB $5 \mathrm{~ms}$ column $(30 \mathrm{~mL} \times 0.25 \mathrm{~mm}$ ID $\times 0.25 \mu \mathrm{m})$. For GC-MS detection, an electron ionization system was operated in electron impact mode with ionization energy of $70 \mathrm{eV}$. Helium gas $(99.999 \%)$ was used as a carrier gas at a constant flow rate of $1.0 \mathrm{~mL} \mathrm{~min}^{-1}$ and an injection volume of $1 \mu \mathrm{L}$ was employed in a splitless mode. The initial temperature was $40^{\circ} \mathrm{C}$ with a hold time of $2 \mathrm{~min}$ and the ramp was $300^{\circ} \mathrm{C}$ at a rate of $10^{\circ} \mathrm{C} / \mathrm{min}$ for a hold period of $5 \mathrm{~min}$. Mass spectra were taken at a scan mass range of $30-600 \mathrm{~m} / \mathrm{z}$. The solvent delay was 0 to $2 \mathrm{~min}$ and the total GC/MS running time was $32 \mathrm{~min}$. The relative percentage amount of each component was calculated by comparing its average peak area to the total areas. Quadrupole mass analyzer along with Xcalibur and AMDIS software was adopted to handle mass spectra and chromatograms. Fatty Acid Methyl
Esters (FAMEs) were quantified by taking the ratio of the integral of each FAME's total ion current peak to that of the internal standard $(50 \mu \mathrm{g})$.

\section{RESULTS}

Six species of Chlorella were identified namely Chlorella vulgaris, C. pyrenoidosa, C. ellipsoidea, C. emersonii, $C$. sorokiniana and $C$. protothecoides. Bioassay experiments involving $\mathrm{Cu}$ concentrations $0.5,1.0,2.0,4.0$ and $8.0 \mathrm{mg} \mathrm{L}^{-1}$ were carried during which cell count and biomass content were varied with $\mathrm{Cu}$ concentration. Highest cell count and biomass was obtained at $4.0 \mathrm{mg} \mathrm{L}{ }^{-1}$ concentrations and was considered for determination of chlorophyll, total protein and lipid content.

The influence of copper stress among Chlorella species has been studied and a concentration dependent reduction in growth rate, content of chlorophyll, protein and lipid were compared and depicted in Fig. 1-5. Among the Chlorella species, $C$. vulgaris has produced maximum biomass $\left(1.18 \mathrm{~g} \mathrm{~L}^{-1}\right)$ followed by $C$. pyrenoidosa and $C$. protothecoides. There were no significant differences in biomass content among the other species studied. The total chlorophyll content estimation revealed that amount of chlorophyll was in the range between $1.7-3.45 \%$. Highest chlorophyll content was present in C. vulgaris (3.45\%), C. pyrenoidosa $(2.21 \%)$ and $C$. protothecoides $(2.17 \%)$. The total protein estimation of isolated Chlorella species revealed the highest content in $C$. protothecoides $\left(0.70 \mathrm{mg} \mathrm{g}^{-1}\right), C$. ellipsoidea $\left(0.69 \mathrm{mg} \mathrm{g}^{-1}\right)$ and $C$. vulgaris $(0.61 \mathrm{mg}$ $\left.\mathrm{g}^{-1}\right)$. The least protein content was found in $C$. emersonii $\left(0.43 \mathrm{mg} \mathrm{g}^{-1}\right)$. The total lipid estimation of the isolates revealed the lipid content between 0.02 $0.11 \mathrm{mg} \mathrm{g}^{-1}$, where $C$. vulgaris $\left(0.21 \mathrm{mg} \mathrm{g}^{-1}\right)$ has recorded highest content followed by $C$. protothecoides $\left(0.17 \mathrm{mg} \mathrm{g}^{-1}\right)$.

GC-MS analysis of the transesterified lipid extracts revealed the presence of various fatty acid groups (C15:0, C16:0, C16:1, C17:1, C18:0, C18:1, C18:2). The percent composition of fatty acids varied among the species studied and the major group of fatty acids were C16:0, C18:1 and C18:2 (Table 1).

In general, copper has influenced the fatty acid composition with various percent compositions. Highest percent of $\mathrm{C} 16: 0$ (25.21\%), C16:1 (2.67\%), C18:0 $(6.2 \%)$ and $\mathrm{C} 18: 2(21.43 \%)$ were found in $C$. vulgaris whereas, C15:0, C17:1 and C18:1 were found in $C$. protothecoides at $1.72,0.91$ and $12.13 \%$ respectively. 
Sibi, G. et al. / OnLine Journal of Biological Sciences 14 (3): 209-217, 2014

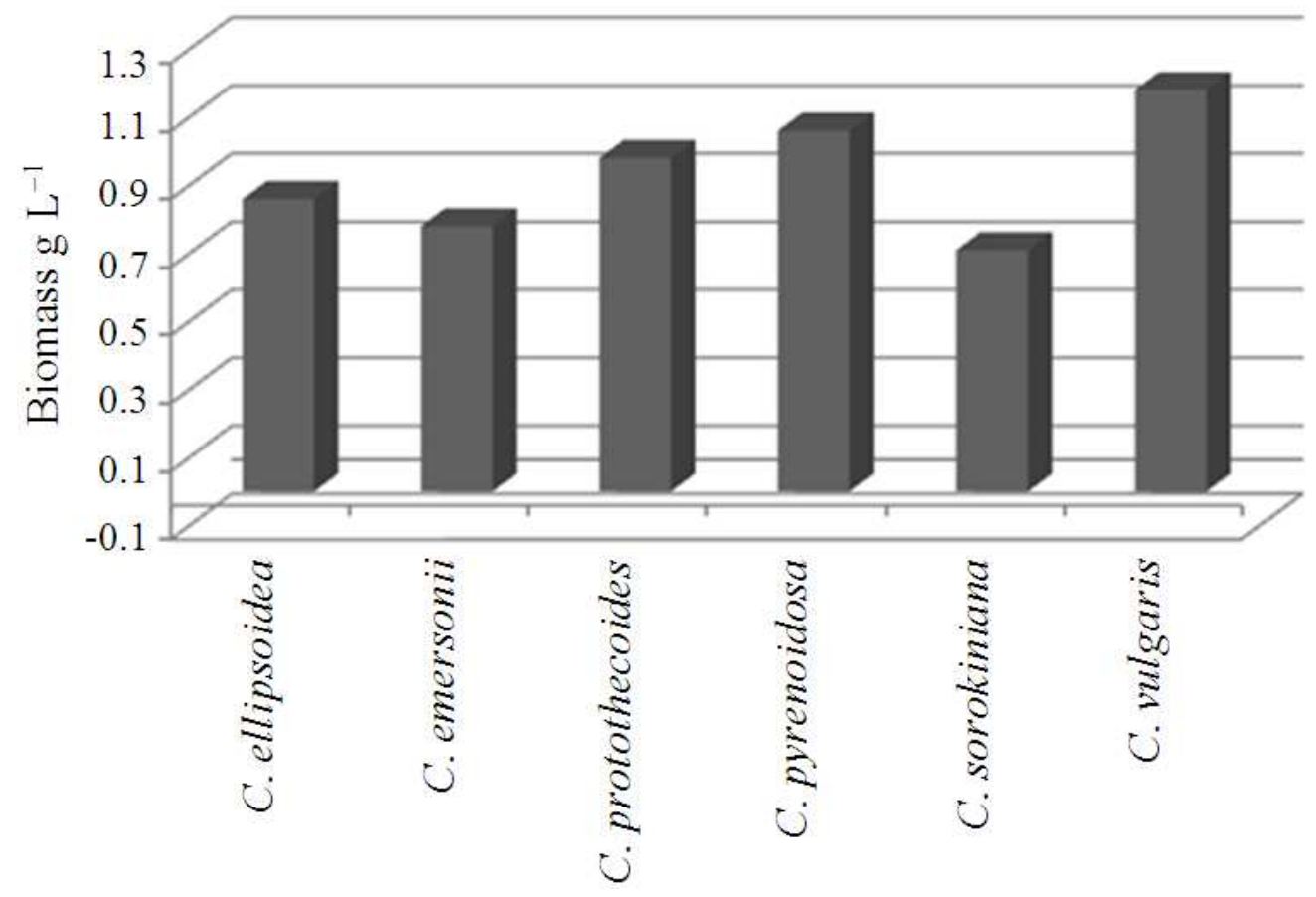

Fig. 1. Biomass content of Chlorella species under copper stress

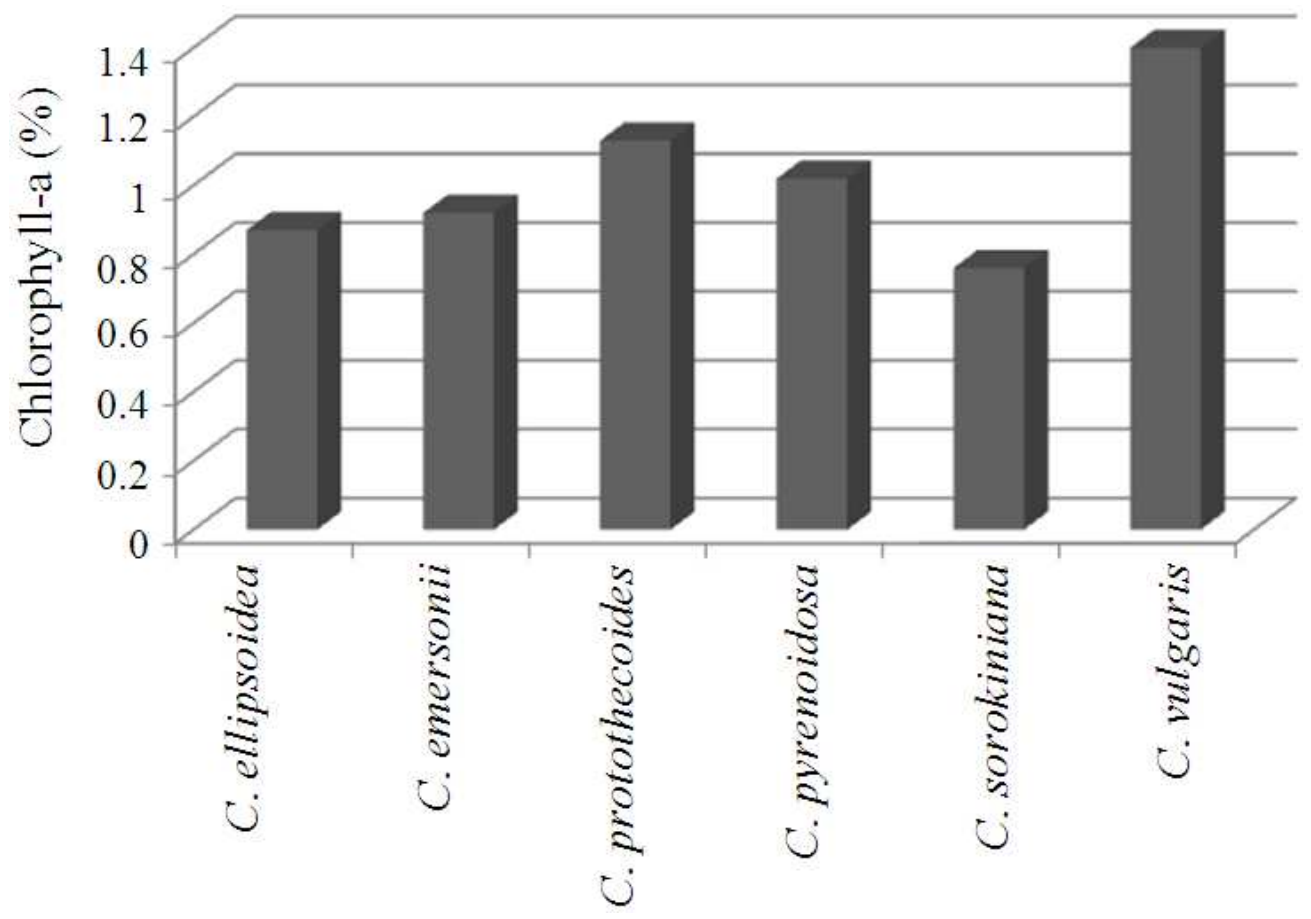

Fig. 2. Chlorophyll-a content of Chlorella species under copper stress 
Sibi, G. et al. / OnLine Journal of Biological Sciences 14 (3): 209-217, 2014

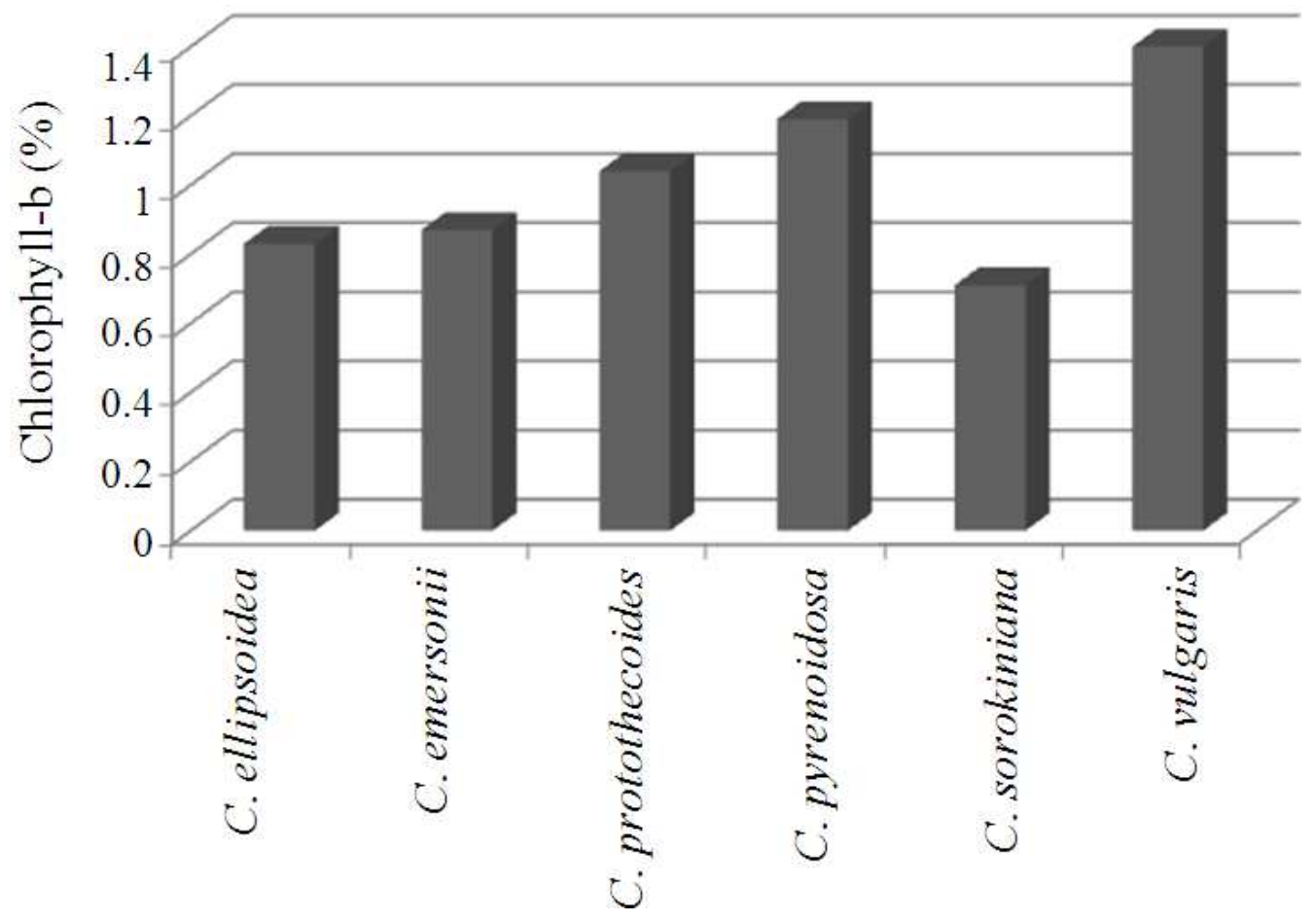

Fig. 3. Chlorophyll-b content of Chlorella species under copper stress

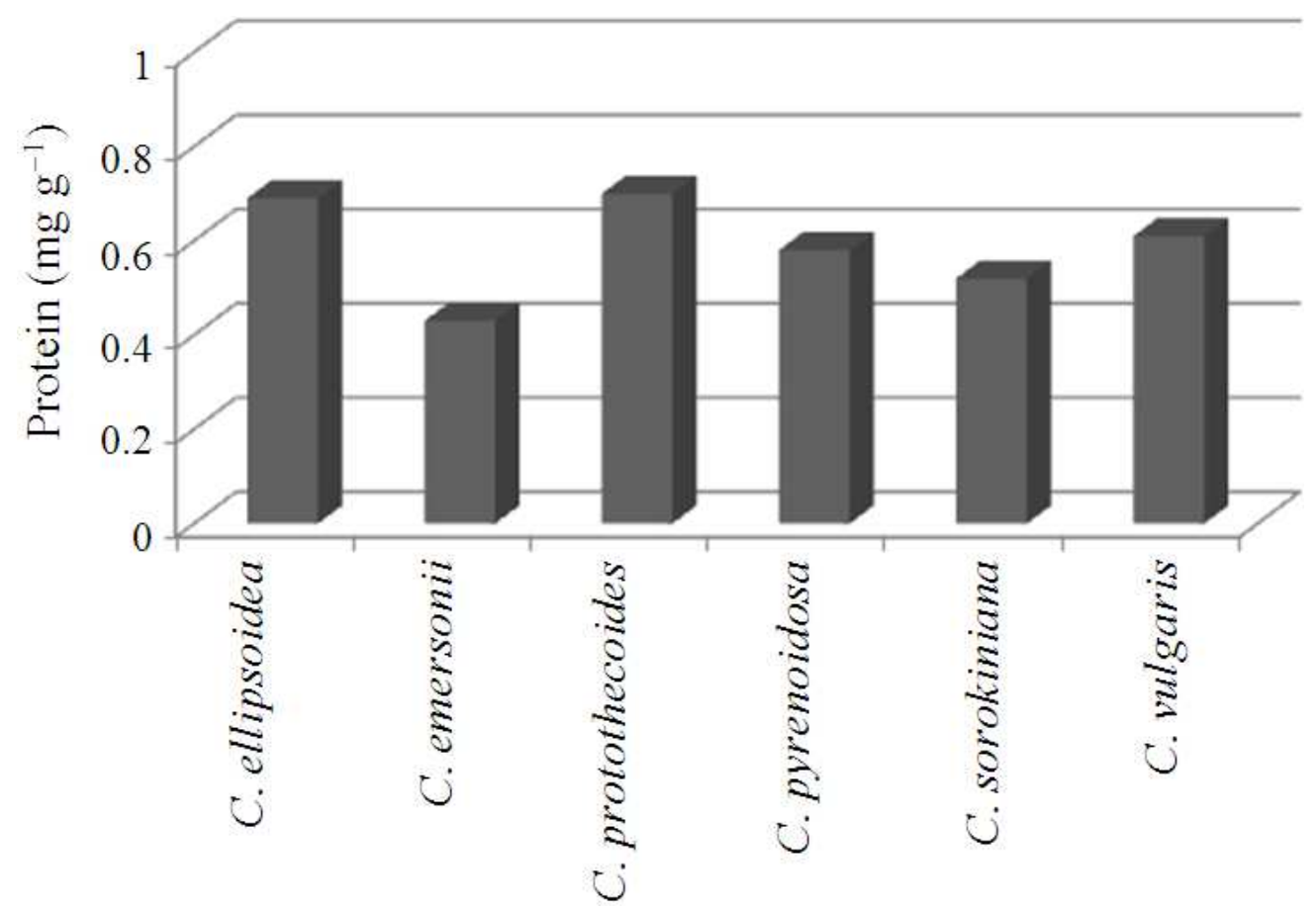

Fig. 4. Protein content of Chlorella species under copper stress 


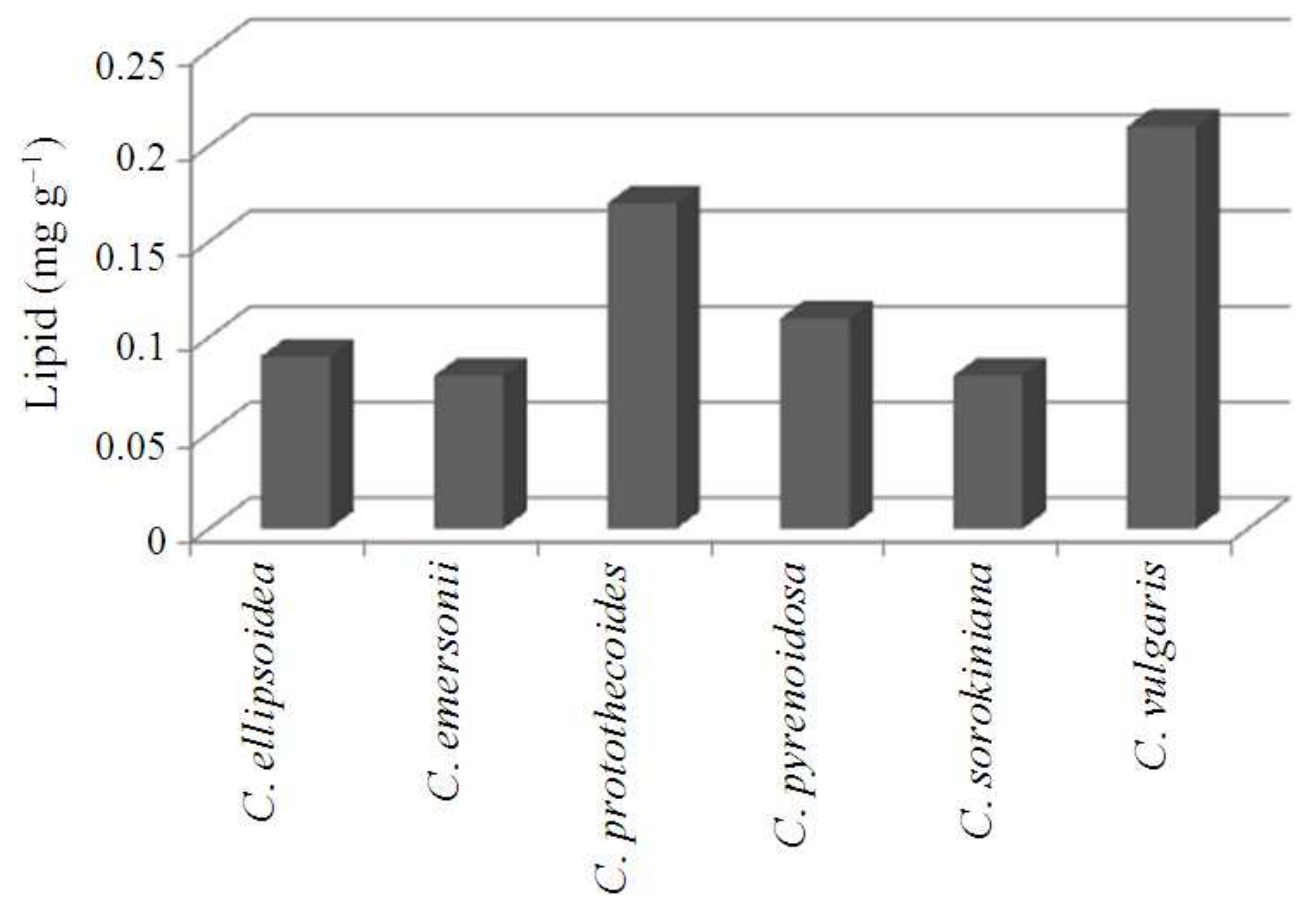

Fig. 5. Lipid content of Chlorella species under copper stress

Table 1. Percent composition of fatty acids from Chlorella species under copper stress $\left(4 \mathrm{mg} \mathrm{L}^{-1}\right)$

\begin{tabular}{llllllrr}
\hline Species & C15:0 & C16:0 & C16:1 & C17:1 & C18:0 & C18:1 & C18:2 \\
\hline C. ellipsoidea & 1.67 & 9.03 & 1.61 & ND & ND & 7.04 & 11.13 \\
C. emersonii & ND & 11.25 & ND & ND & 0.81 & 7.73 & 12.93 \\
C. protothecoides & 1.72 & 18.42 & 1.85 & 0.91 & ND & 12.13 & 19.01 \\
C. pyrenoidosa & ND & 16.71 & ND & 0.25 & 2.64 & 7.92 & 12.24 \\
C. sorokiniana & 0.74 & 8.63 & 0.91 & ND & 0.71 & 3.05 & 6.79 \\
C. vulgaris & 1.53 & 25.21 & 2.67 & ND & 6.2 & 11.03 & 21.43 \\
\hline
\end{tabular}

\section{DISCUSSION}

Most of the oleaginous algae belong to green algae and diatoms (Pulz and Gross, 2004). Green algae have more saturated and unsaturated fatty acids similar to that of vegetable oils. Chlorella species are particularly attractive due to their strong resistance characteristics to various unfavourable environmental conditions. Association of increased cellular lipid accumulation under different environmental stress conditions was observed in green microalgae (Li et al., 2011b). During biofuel production, high lipid production is crucial to achieve commercial feasibility. A suitable microalgae strain must have high lipid productivity, either by possessing high basal lipid content and/or be inducible to accumulate significant amounts of lipids (Rodolfi et al., 2009). Previous studies concerning the heavy metal tolerance of algal species were reported (Bajguz, 2000; Takamura et al., 1989). Heavy metals can cause adverse effects on cell division, growth, photosynthesis and respiration (Wang and Chen, 2009). Variations in cell number, chlorophyll and protein content among the Chlorella species were observed in this study which could be due to copper exposure of Chlorella. Copper has been found to be one of more toxic metals to unicellular algae than other heavy metals (Bilgrami and Kumar, 1997; Ilangovan et al., 1992; Lam et al., 1999; Rachlin and Grosso, 1993). This study focused on effect of copper on growth rate, cellular and lipid composition of Chlorella species.

One of the goals of this study was to find a copper concentration that would not negatively affect the microalgae. It was found that increasing copper concentrations in the bioassay caused a significant decrease in algal growth rates among the Chlorella 
species over 15 days. The growth rate was declined above $4.0 \mathrm{mg} \mathrm{L}^{-1}$ concentration and hence the further experiments were carried out at $4.0 \mathrm{mg} \mathrm{L}^{-1}$ concentration. Copper tolerance by $C$. vulgaris at $3.0 \mu \mathrm{g}$ $\mathrm{m} \mathrm{L} \mathrm{L}^{-1}$ concentration was reported in earlier studies (Mallick, 2004). The next goal was how copper would impact the growth, chlorophyll, protein content and lipid accumulation in Chlorella species. At $4.0 \mathrm{mg}$ $\mathrm{L}^{-1}$, significant cell numbers and biomass concentration were observed among the species. The determination of biomass, chlorophyll and lipid contents of microalgae would provide useful information concerning the growth status during cultivation. High lipid accumulation and biomass productivity are desired phenotypes in algae for biodiesel production. However, stress conditions reduce the biomass production and increase lipid content of algae (Li et al., 2008). In this study, copper have an impact on Chlorella species where biomass content was directly proportional to the lipid productivity. Berglund et al. (2001) reported that both the quantity and quality of lipids produced vary with the identity of algal species. The same trend was observed in this study, where $C$. vulgaris, $C$. protothecoides and C. pyrenoidosa produced higher percent composition of fatty acids than other species.

\section{CONCLUSION}

In the case of value added products from microalgae, the isolates should adapt better to heavy metal stress and provide a more stable and productive culture in pilot scale. Most of the isolates were able to tolerate copper and produced diversified fatty acids at various concentrations irrespective of the species. Biochemical adaptations to abiotic stresses involve evolution of new metabolic pathways and synthesis of new proteins and the copper stress has influenced the lipid profile of microalgae in this study. This research presented here reflects the fact that copper stress on Chlorella species as the evidence of lipid production in both qualitative and quantitative manner. The presence of diversified fattyacids under copper stress is an evidence that Chlorella can be used for the sustainable production of renewable energy and other nutraceuticals. It also suggests the use of this species for the removal of copper from aqueous solutions. Further research on influence of other heavymetals in the cellular and lipid contents of Chlorella species need to be investigated for the efficeint use of the microalgae in the production of other value added products.

\section{ACKNOWLEDGMENT}

The researchers are grateful to Karnataka State Biofuel Development Board and Karnataka State Council for Science and Technology vide No. 37S_B_MSc_023 for the financial support.

\section{REFERENCES}

Anderson, R.A., 1996. Algae. In: Maintaining Cultures for Biotechnology and Industry, HunterCevera, J.C. and A. Belt (Eds.)., London Academic Press, Inc., ISBN-10: 978-0-12-361946-4, pp: 29-64.

Andersen, R.A., 2005. Algal Culturing Techniques. 1st Edn., Elsevier Academic Press. California, USA, ISBN-10: 0120884267, ppp: 578.

Bajguz, A., 2000. Blockade of heavy metals accumulation in Chlorella vulgaris cells by $24-$ epibrassinolide. Plant Physiol. Biochem., 38: 797801. DOI: $10.1016 / \mathrm{S} 0981-9428(00) 01185-2$

Berglund, O., P. Larsson, G. Ewald and L. Okla, 2001. The effect of lake trophy on lipid content and PCB concentrations in planktonic food webs. Ecology, 82: 1078-1088. DOI: 10.1890/0012-9658

Bilgrami, K.S. and S. Kumar, 1997. Effects of copper, lead and zinc on phytoplankton growth. Biol. Plantarum, 39 : $315-317 . \quad$ DOI: 10.1023/A: 1000600503710

Bradford, M.M., 1976. A rapid and sensitive method for the quantitation of microgram quantities of protein utilizing the principle of protein-dye binding. Analytical Biochem., 72: 248-254. DOI: 10.1016/0003-2697(76)90527-3

Breuer, C., K. Morohashi, A. Kawamura, N. Takahashi and T. Ishida et al., 2012. Transcriptional repression of the $\mathrm{APC} / \mathrm{C}$ activator $\mathrm{CCS} 52 \mathrm{~A} 1$ promotes active termination of cell growth. EMBO J., 31: 44884501. DOI: 10.1038/emboj.2012.294

Chisti, Y., 2007. Biodiesel from microalgae. Biotechnol. Adv., 25: 294-306. DOI: 10.1016/j.biotechadv.2007.02.001

Cid, A., P. Fidaglogo, C. Herrero and J. Abalde, 1996. Toxic action of copper on the membrane system of a marine diatom measured by flow cytometry. Cytometry, 25: 32-36. DOI: 10.1002/(SICI)10970320(19960901)25

Dragone, G., B.D. Fernandes, A.P. Abreu, A.A. Vicente and J.A. Teixeira, 2011. Nutrient limitation as a strategy for increasing starch accumulation in microalgae. Applied. Energy, 88: 3331-3335. DOI: 10.1016/j.apenergy.2011.03.012 
Folch, J., M. Lees and G.H. Sloane-Stanley, 1957. A simple method for the isolation and purification of total lipides from animal tissues. J. Biol. Chem., 226: 497-509. PMID: 13428781

Griffiths, M.J. and S.T.L. Harrison, 2009. Lipid productivity as a key characteristic for choosing algal species for biodiesel production. J. Applied Phycol., 21: 493-507. DOI: 10.1007/s10811-008-9392-7

Horne, A.J. and C.R. Goldman, 1974. Suppression of nitrogen fixation by blue-green algae in a eutrophic lake with trace additions of copper. Science, 183: 409-411. DOI: 10.1126/science.183.4123.409

Hsieh, C.H. and W.T. Wu, 2009. Cultivation of microalgae for oil production with a cultivation strategy of urea limitation. Bioresour. Technol., 100: 3921-3926. DOI: 10.1016/j.biortech.2009.03.019

$\mathrm{Hu}$, Q., M. Sommerfeld, E. Jarvis, M. Ghirardi and M. Posewitz et al., 2008. Microalgal triacylglycerols as feedstocks for biofuel production: Perspectives and advances. Plant J., 54: 621-639. DOI: 10.1111/j.1365-313X.2008.03492.x

Huang, G.H., F. Chen, D. Wei, X.W. Zhang and G. Chen, 2010. Biodiesel production by microalgal biotechnology. Applied Energy, 87: 38-46. DOI:10.1016/j.apenergy.2009.06.016

Ilangovan, K., M. Salazar, S. Dash, O. Monroy and A. Ramos, 1992. Interaction of cadmium, copper and zinc in Chlorella pyrenoidosa Chick. Environ. Technol., 13: 195-199. DOI: 10.1080/09593339209385144

Lam, P.K.S., P.F. Wut, A.C.W. Chan and R.S.S. Wu, 1999. Individual and combined effects of cadmium and copper on the growth response of Chlorella vulgaris. Environ. Toxicol., 14: 347-353. DOI: 10.1002/(SICI)1522-7278(199907)

Li, Y., M. Horsman, B. Wang, N. Wu and C.Q. Lan, 2008. Effects of nitrogen sources on cell growth and lipid accumulation of green alga Neochloris oleoabundans. Applied Microbiol. Biotechnol., 81: 629-636. DOI: 10.1007/s00253-008-1681-1

Li, X., H.Y. Hu and Y.P. Zhang, 2011a. Growth and lipid accumulation properties of a freshwater microalga Scenedesmus sp. under different cultivation temperature. Bioresour. Technol., 102: 3098-3102. DOI: 10.1016/j.biortech.2010.10.055

Li, Y., D. Han, M. Sommerfeld and Q. Hu, 2011 b. Photosynthetic carbon partitioning and lipid production in the oleaginous microalga Pseudochlorococcum sp. (Chlorophyceae) under nitrogen-limited conditions. Bioresour. Technol., 102: 123-129. DOI: 10.1016/j.biortech.2010.06.036
Liu, Z.Y., G.C. Wang and B.C. Zhou, 2008. Effect of iron on growth and lipid accumulation in Chlorella vulgaris. Bioresour. Technol., 99: 4717-4722. DOI: 10.1016/j.biortech.2007.09.073

Mallick, N., 2004. Copper-induced oxidative stress in the chlorophycean microalga Chlorella vulgaris: Response of the antioxidant system. J. Plant Physiol., 161: 591597. DOI: 10.1078/0176-1617-01230

Marschner, H., 1995. Mineral Nutrition of Higher Plants. 3rd Edn., Academic Press, London, ISBN-10: 0123849063, pp: 672.

OECD, 2002. Guidelines for the testing of chemicals. Fresh water Alga and Cyanobacteria, Growth Inhibition Test.

Petkov, G. and G. Garcia, 2007. Which are fatty acids of the green alga Chlorella? Biochem. Sys. Ecol., 35: 281-285. DOI: 10.1016/j.bse.2006.10.017

Pulz, O. and W. Gross, 2004. Valuable products from biotechnology of microalgae. Applied Microbiol. Biotechnol., 65: 635-648. DOI: 10.1007/s00253004-1647-x

Rachlin, J.W. and A. Grosso, 1993. The growth response of the green alga Chlorella vulgaris to combined divalent cation exposure. Archives Environ. Contamination Toxicol., 24: 16-20. DOI: 10.1007/BF01061084

Rai, L.C., J.P. Gaur and H.D. Kumar, 1981. Phycology and heavy metal pollution. Biolog. Rev., 56: 99-151. DOI: 10.1111/j.1469-185X. 1981.tb00345.x

Rocchetta, I., M. Mazzuca, V. Conforti, L. Ruiz and V. Balzaretti et al., 2006. Effect of chromium on the fatty acid composition of two strains of Euglena gracilis. Environ. Pollut., 141: 353-358. DOI: 10.1016/j.envpol.2005.08.035

Rodolfi, L., G.C. Zittelli, N. Bassi, G. Padovani and N. Biondi et al., 2009. Microalgae for oil: Strain selection, induction of lipid synthesis and outdoor mass cultivation in a low-cost photobioreactor. Biotechnol. Bioeng., 102: 100-112. DOI: 10.1002/bit.22033

Round, F.E., 1973. The biology of the algae. J. Marine Biolog. Associat. United Kingdom, 45: 799-799. DOI: $10.1017 / \mathrm{S} 0025315400016672$

Sartory, D.P. and J.U. Grobbelaar, 1984. Extraction of chlorophyll a from freshwater phytoplankton for spectrophotometric analysis. Hydrobiologia, 114: 177-187. DOI: 10.1007/BF00031869 
Stanier, R.Y., R. Kunisawa, M. Mandel and G. CohenBazire, 1971. Purification and properties of unicellular blue- green algae (order Chroococcales). Bacteriol. Rev., 35: 171-205. PMID: 378380

Stauber, J.L. and T.M. Florence, 1987. The mechanism of toxicity of ionic copper and copper complexes to algae. Marine Biol., 94: 511-519. DOI: 10.1007/BF00431397

Sunda, W.G., N.M. Price, and F.M.M. Morel, 2005. Trace Metal Ion Buffers and their Use in Culture Studies. In: Algal Culturing Techniques, R., Anderson, (Ed.,), Elsevier Academic Press, pp: 3563.

Takagi, M.K. and T. Yoshida, 2006. Effect of salt concentration on intracellular accumulation of lipids and triacylglyceride in marine microalgae Dunaliella cells. J. Biosci. Bioeng., 101: 223-226. DOI: $10.1263 /$ jbb.101.223
Takamura, N., F. Kusai and M. Watanabe, 1989. Effects of $\mathrm{Cu}, \mathrm{Cd}, \mathrm{Zn}$ on photosynthesis of freshwater benthic algae. J. Applied Phycol., 1: 39-52. DOI: $10.1007 / \mathrm{BF} 00003534$

Vavilin, D.V., J.M. Ducruet, D.N. Matorin, P.S. Venediktov and A.B. Rubin, 1998. Membrane lipid peroxidation, cell viability and Photosystem II activity in the green alga Chlorella pyrenoidosa subjected to various stress conditions. J. Photochem. Photobiol. Biol., 42: 233-239. DOI: 10.1016/S1011-1344(98)00076-1

Wang, J. and C. Chen, 2009. Biosorbents for heavy metals removal and their future. Biotechnol. Adv., 27 : 195-226.

DOI: 10.1016/j.biotechadv.2008.11.002 